\title{
Prototype Sistem Monitoring Kesehatan Terintegrasi dengan Keluaran Pada Smartphone Android
}

\author{
Derisma $^{{ }^{*}}$, Moch. Harvie Saputra ${ }^{2}$ \\ 1,2 Program Studi Sistem Komputer, Fakultas Teknologi Informasi, Universitas Andalas \\ Limau Manis Kec. Pauh, Kota Padang, Sumatera Barat \\ Indonesia 25163 \\ *email:derisma@fti.unand.ac.id
}

(Naskah masuk: 03 Februari 2020; diterima untuk diterbitkan: 03 Maret 2020)

\begin{abstract}
ABSTRAK - Penelitian ini bertujuan untuk merancang sistem monitoring kesehatan terintegrasi dengan keluaran pada smartphone android menggunakan sensor suhu DS18B20, Pulse Sensor, Sensor Suara dan Sensor Galvanic Skin Response. Prinsip kerjanya dimana alat akan membaca data dari tubuh dengan empat nilai yang diukur yaitu suhu tubuh, detak jantung melalui denyut nadi, keringat, dan pernapasan selanjutnya nilai tersebut dikirim ke smartphone dan ditampilkan pada aplikasi mobile. Data yang tampil pada layar smartphone dapat disimpan dan dilihat riwayat pembacaannya. Hasil pembacaan oleh alat sudah cukup baik didapatkan rata-rata error sensor suhu DS18B20 sebesar $2,51 \%$, sensor pernapasan sebesar $16,4 \%$, pulse sensor sebesar $37 \%$. Nilai yang didapatkan ketika keadaan santai atau sebelum beraktivitas terjadi peningkatan setelah beraktivitas seperti olahraga lari $100 \mathrm{~m}$, diantaranya peningkatan detak jantung yakni 54 BPM ke 61 BPM setelah lari 100m, Peningkatan pernapasan yaitu 18 kali/menit ke 29 kali/ menit serta didapatkan juga peningkatan suhu dari $34.19^{\circ} \mathrm{C}$ ke $35,18^{\circ} \mathrm{C}$.
\end{abstract}

Kata Kunci-DS18B20, Pulse Sensor, Sensor Suara, Galvanic Skin Response, Mobile Application

\section{Prototype of the Integrated Health Monitoring System with Outputs on Android Smartphones}

\begin{abstract}
This research aims to design an integrated health monitoring system with output on Android smartphones using a DS18B20 temperature sensor, Pulse Sensor, sound Sensor, and Galvanic Skin Response Sensor. The principle of its work in which the tool will read data from the body with four values measured, namely body temperature, heart rate through pulse, sweat, and subsequent breathing, the value is sent to the smartphone and displayed on the Mobile Application. The Data displayed on the smartphone screen can be saved and viewed by the reading history. The result of reading by the tool was kind enough to get the average error sensor temperature DS18B20 of $2.51 \%$, respiratory sensor of $16.4 \%$, pulse sensor of $37 \%$. The value obtained when the condition is relaxed or before the activity occurs increase after activities such as $100 \mathrm{~m}$ running sports, including an increase in heart rate of 54 $B P M$ to 61 BPM after $100 \mathrm{~m}$ dash, increased breathing is 18 times/minute to 29 times/minute and also obtained an increase in temperature from $34.19 \mathrm{oC}$ to $35.18^{\circ} \mathrm{C}$.
\end{abstract}

Keywords - DS18B20, Pulse Sensor, Sound Sensor, Galvanic Skin Response, Mobile Application

\section{Pendahuluan}

Pengertian eHealth menurut World Health Organization (WHO), yaitu "the use of Information and Communication Technologies (ICT) for health to, for example, treat patients, pursue research, educate students, track diseases and monitor public health". Sementara dalam KepMenKes Nomor 192/MENKES/SK/VI/2012 disebutkan bahwa eHealth adalah pemanfaatan TIK di sektor kesehatan terutama untuk meningkatkan pelayanan kesehatan. 
Hingga kini telah banyak perangkat yang dipakai untuk mengecek keadaan seorang seperti termometer yang dipergunakan untuk mengukur suhu tubuh, Pulse Oximeter untuk mencek keadaan detak jantung apakah berdetak normal atau tidak, tetapi alat tersebut hanya terbatas pada satu penilaian saja dimana satu perangkat hanya untuk satu jenis pengecekan. Alat-alat seperti termometer dan stetoskop memang sudah lazim digunakan oleh tenaga medis untuk memantau pasien. Akan tetapi alat-alat tersebut digunakan secara terpisah dalam penggunaannya

Pada beberapa penelitian terdahulu sudah ada yang menbuat alat terpisah untuk memeriksa pernafasan [1][2][3][4], suhu [5][6][7], jantung [8][9] [10][11] atau dengan menggabungkan beberapa alat ukur kesehatan [12][13][14] dimana alat tersebut gabungan dari tiga buah komponen ukur yaitu untuk mengukur suhu, pernapasan dan denyut nadi dan di tampilkan ke dalam LCD. Namun data yang diperlihatkan hanya di LCD. Ada juga yang ditampilkan ke web namun tidak efektif digunakan selama berolahraga [15]

Dari permasalahan diatas dirancanglah sebuah perangkat monitoring kesehatan terintegrasi dengan keluaran pada smartphone android dimana alat ini nantinya akan mengukur suhu, pernapasan, keringat, dan detak jantung selanjutnya akan disimpan dan dilihat hasil serta riwayatnya pada smartphone android.

\section{METODE DAN BAHAN}

Jenis penelitian yang digunakan penelitian eksperimental (experimental research). Berdasarkan Gambar 1, Sensor yang digunakan diantaranya sensor suhu (DS18B20), sensor keringat (Galvanic Skin Response (GSR)), sensor Pernapasan (Sensor Suara), Sensor Detak Jantung (Pulse Sensor). Masing masing untuk membaca suhu tubuh, keringat, pernapasan, dan detak jantung. Arduino adalah tempat proses data-data yang telah dibaca oleh sensor. Liquid Crystal Display (LCD) untuk menampilkan data sementara dari pembacaan sensor. Modul bluetooth berfungsi sebagai media pengiriman data ke smartphone android. Smartphone sebagai tempat menerima data yang dikirim oleh alat dan menampilkan data melalui aplikasi mobile, data yang dibaca dapat disimpan dan data yang disimpan dapat dilihat pada riwayat.

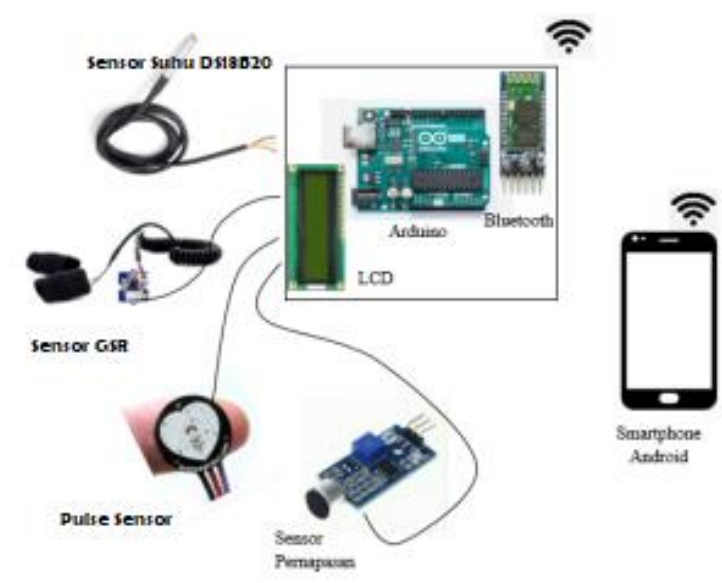

Gambar 1. Rancangan Perangkat Keras

Alur proses dari sistem secara keseluruhan seperti pada Gambar 2 dimulai dari inisialisasi pin pada arduino. Setelah itu alat dihidupkan pertama tekan tombol untuk memulai, lalu pembacaan data dimulai dari pembacaan yang dilakukan satu-persatu oleh sensor pertama dilakukan oleh sensor pembaca detak jantung melalui denyut nadi dengan menggunakan sensor pulse sensor dalam satuan BPM (detak per menit), nilai lalu ditampilkan pada LCD, setelah itu pembacaan sensor pernapasan menggunakan sensor suara dimana suara dalam bernafas yang akan dihitung dalam satu menit dan di tampilkan ke LCD. Pembacaan selanjutnya yaitu pembacaan data keringat menggunakan sensor GSR (Galvanic Skin Response) keringat yang dibaca dalam volt di tampilkan ke LCD, dan terakhir pembacaan suhu menggunakan sensor Suhu DS18B20. Pambacaan sensor ini dapat digenggam atau diletakkan di ketiak dan hasilnya akan tampil ke LCD juga. Proses selanjutnya setelah pembacaan data dari keempat sensor tersebut selesai maka data akan di kirim dalam kurun waktu satu menit ke smartphone android melalui bluetooth. Data dapat di simpan dan dapat di lihat rekam riwayatnya pada history.

Adapun rancangan pada interface aplikasi android diperlihatkan pada Gambar 3. 


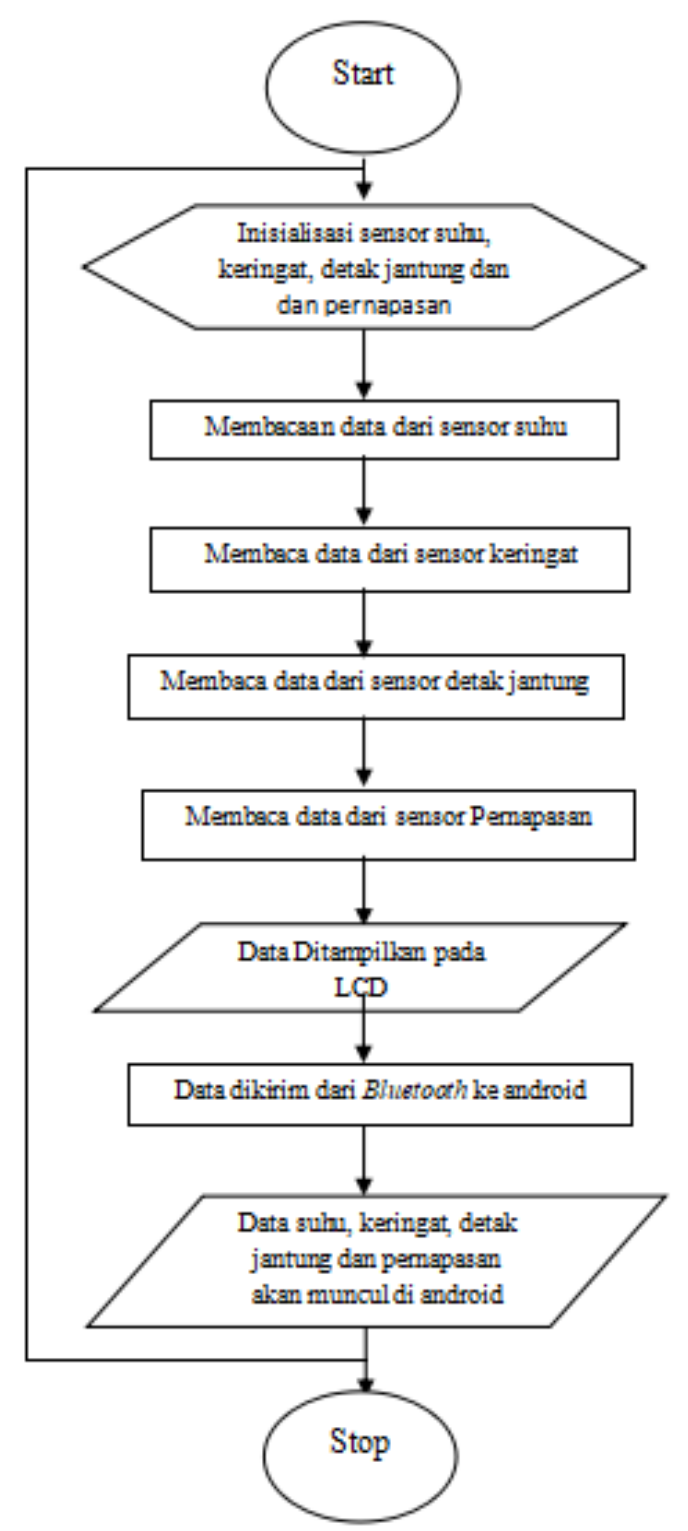

Gambar 2. Rancangan Proses
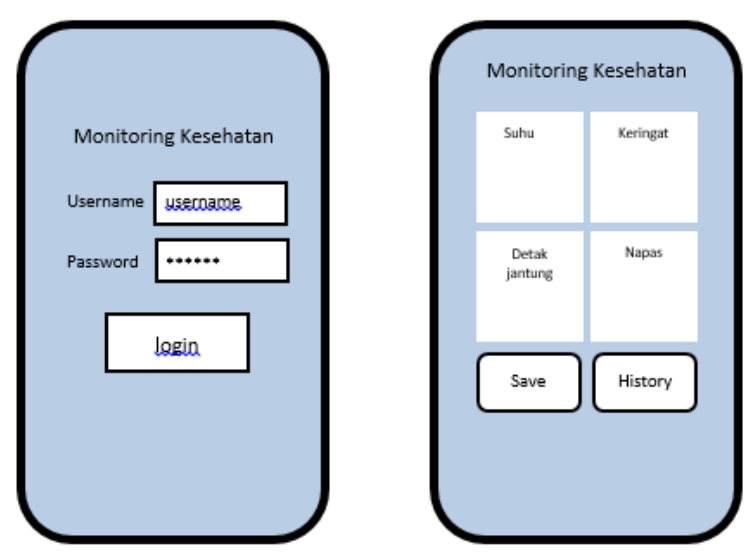

Gambar 3. Rancangan Interface

\section{HASIL DAN PEMBAHASAN}

Sistem ini diimplementasikan menggunakan beberapa perangkat keras, diantaranya sensor suhu DS18B20, Galvanic Skin Response (GSR), pulse sensor, sensor suara, arduino, LCD, Modul Bluetooth HC-05, power supply. Implementasi perangkat keras ditunjukkan pada Gambar 4.

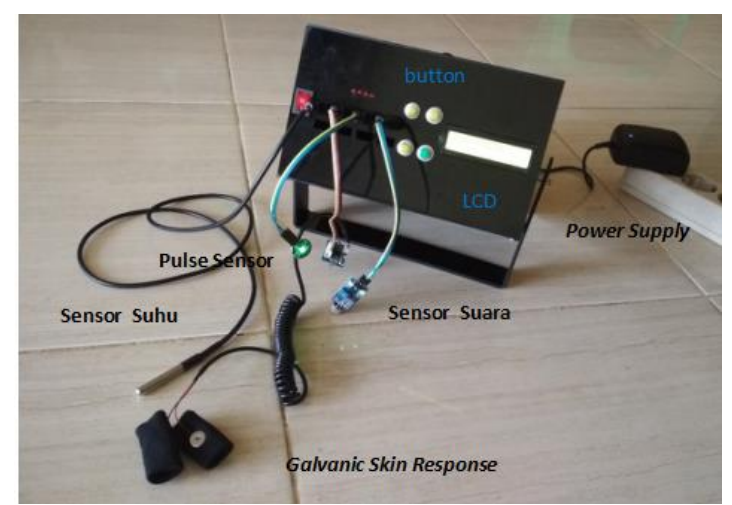

Gambar 4. Tampilan Perangkat Keras

Dari hasil pengujian sensor pada Tabel 1 diperoleh hasil pembacaan sensor suhu DS18B20 dengan termometer didapatkan rata-rata error sebesar 2,51\%. Jadi dapat disimpulkan dengan persentase rata-rata error yang kecil, sensor DS18B20 bisa digunakan sebagai alat untuk mengukur suhu tubuh. Pengujian sensor pernapasan menggunakan sensor suara dengan frekuensi pernapasan menggunakan stopwatch didapatkan hasil rata-rata error sebesar $16,4 \%$. Berdasarkan hasil pengujian ini dapat diperoleh bahwa hasil pembacaan sensor suara relatif tidak terlalu jauh berbeda dengan hasil perhitungan frekuensi pernapasan yang dihitung secara manual.

Tabel 1. Hasil Pengujian Sensor

\begin{tabular}{clc}
\hline No & Sensor & Rata-rata \% Error \\
\hline 1 & Sensor Suhu & 2,51 \\
2 & Sensor Pernapasan & 16,4 \\
3 & Sensor Detak Jantung & 37 \\
\hline
\end{tabular}

Berdasarkan hasil pengujian antara pulse sensor dengan pulse oximeter didapatkan hasil rata-rata error sebesar 37\%, dengan error tertinggi sebesar $44,8 \%$. Error ini disebabkan oleh lambatnya respon dari pulse sensor dan kurang tepatnya peletakan jari sehingga lambat pembacaannya. Jadi dapat disimpulkan bahwa dalam penggunaan pulse sensor 
harus teliti dan tepat dalam meletakkan jari ketika pembacaan oleh sensor berlangsung. Berdasarkan pengujian ini diperoleh hasil bahwa sensor GSR dapat bekerja dengan baik. Pengujian untuk sensor GSR berdasarkan Tabel 2 diperoleh hasil bahwa sensor GSR dapat tampil pada LCD dengan baik.

Tabel 2. Pengujian Sensor Keringat

\begin{tabular}{cc}
\hline $\begin{array}{c}\text { Nilai yang didapat sensor } \\
\text { GSR }(\mathrm{v})\end{array}$ & Tampil Pada LCD \\
\hline 1,35 & Tampil \\
1,50 & Tampil \\
1,26 & Tampil \\
\hline
\end{tabular}

Pengujian di Tabel 3 dilakukan untuk melihat respon dari komunikasi android dengan Arduino melalui bluetooth. Saat sistem mulai dijalankan maka bluetooth akan disambungkan dengan android melalui aplikasi pada smartpone menggunakan BT_Port pada layar. Pengujian dilakukan untuk mengetahui jarak maksimal yang bisa komunikasi antara bluetooth dengan android. Tabel 3 merupakan hasil pengujian modul bluetooth.

Tabel 3. Pengujian Bluetooth HC-05

\begin{tabular}{ccc}
\hline $\begin{array}{c}\text { Percobaan } \\
\text { Ke }\end{array}$ & Jarak (m) & $\begin{array}{c}\text { Koneksi } \\
\text { Bluetooth }\end{array}$ \\
\hline 1 & 0,5 & Terhubung \\
2 & 1 & Terhubung \\
3 & 1,5 & Terhubung \\
4 & 2 & Terhubung \\
5 & 2,5 & Terhubung \\
6 & 3 & Terhubung \\
7 & 3,5 & Terhubung \\
8 & 4 & Terhubung \\
9 & 4,5 & Terhubung \\
10 & 5 & Terhubung \\
11 & 5,5 & Terhubung \\
12 & 6 & Terhubung \\
13 & 6,5 & Terhubung \\
14 & 7 & Terhubung \\
15 & 7,5 & Terputus \\
16 & 8 & Terputus \\
\hline
\end{tabular}

Setelah pengujian yang dilakukan dengan pengukuran jarak dari smartphone dengan alat dengan membuat jarang perbandingan $0,5 \mathrm{~m}$ dalam 16 kali pengukuran dan didapatkan pada jarak 7,5m dan $8 \mathrm{~m}$ didapatkan koneksi alat dan smartphone terputus. Berdasarkan pengujian yang telah dilakukan, diperoleh data seperti yang ditunjukkan pada Tabel 4 dan Gambar 5.

Tabel 4. Kesamaan data Output LCD dan Smartphone

\begin{tabular}{cccc}
\hline $\begin{array}{c}\text { Indikator } \\
\text { Sensor }\end{array}$ & $\begin{array}{c}\text { Tampilan } \\
\text { Pada } \\
\text { LCD }\end{array}$ & $\begin{array}{c}\text { Tampilan } \\
\text { Output } \\
\text { Mobile } \\
\text { Application }\end{array}$ & $\begin{array}{c}\text { Kesamaan } \\
\text { Data }\end{array}$ \\
\hline Suhu & 33,88 & 33,88 & Sama \\
Detak & 62 & 62 & Sama \\
Jantung & & & \\
$\begin{array}{c}\text { (BPM) } \\
\text { Pernapasan } \\
\text { (Resp) }\end{array}$ & 18 & 18 & Sama \\
Keringat & 1,88 & 1,88 & Sama \\
(GSR) & & & \\
\hline
\end{tabular}
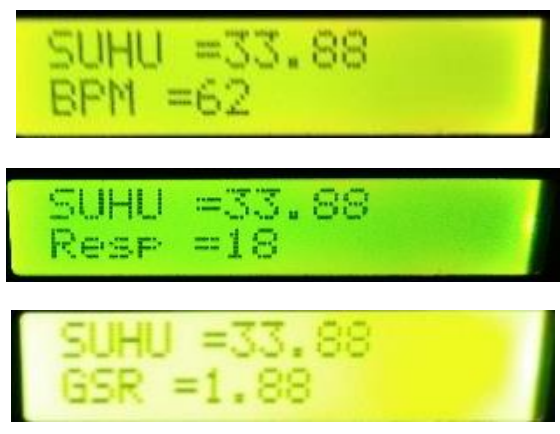

Gambar 5. Tampilan Pada LCD

Pada pengujian mobile application ini akan menguji output keluaran dari alat dibandingkan dengan keluaran yang ditampilkan pada tampilan aplikasi mobile, seperti ditunjukkan pada Gambar 6.

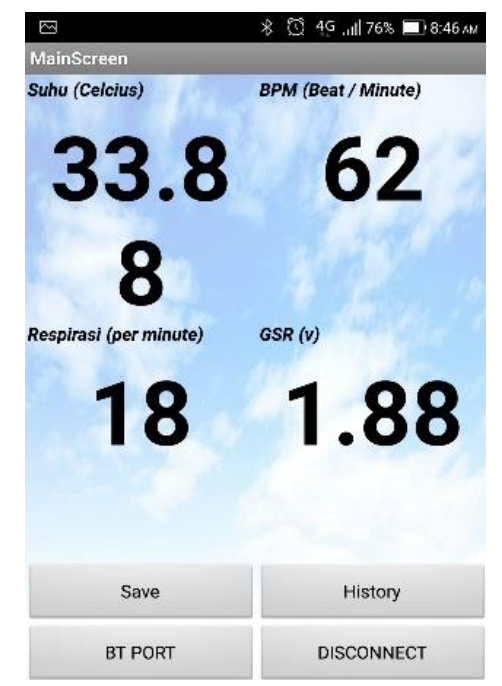

Gambar 6. Tampilan Pada Smartphone 
Setelah pengujian dilakukan dapat disimpulkan bahwa data yang ditampilkan alat pada LCD dikirim dengan tepat oleh bluetooth ke mobile application pada smartphone android.

Pengujian sistem keseluruhan dimana pengujian terhadap alat apakah alat bisa membaca nilai suhu, keringat, detak jantung, dan pernapasan. Pengujian dilakukan ketika dalam kondisi nomal atau santai (sebelum beraktivitas) dan kondisi ketika beraktivitas sedang seperti olahraga ringan lari 100 m. Dalam pengujian alat secara keseluruhan maka pertama alat dihidupkan setelah itu pembacaan dilakukan bergiliran secara continue atau berlanjut, pertama-tama pembacaan dilakukan oleh pulse sensor untuk membaca nilai BPM, selanjutnya pembacaan oleh sensor pernapasan untuk mengukur berapa kali bernapas dalam 1 menitnya, selanjunya yaitu keringat dan suhu pembacaan keringat menggunakan sensor GSR dengan cara memasang alat kedua jari tangan dan untuk suhu memegang atau menggenggam sensor suhu DS18B20. Gambar 7 merupakan peroses pengambilan data proses pembacaanya.

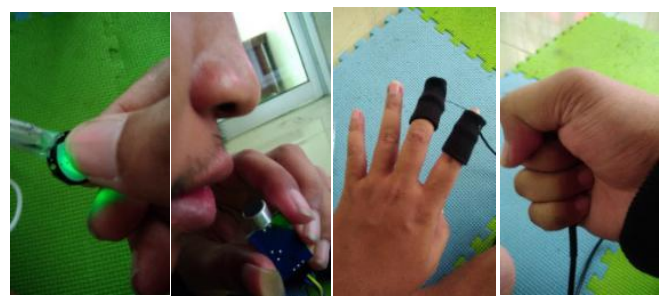

Gambar 7. Proses Pengujian Alat pada User

Setelah pembacaan selesai maka data pembacaaan yang pertama akan di tampilkan pada LCD untuk memilih data yang dilihat bisa menggunakan tombol yang ada pada layar. Setelah data dapat di tampilkan LCD maka data akan dikirim melalui bluetooth dari alat ke mobile application.

Untuk pengujian keseluruhan akan dilakukan dua buah kondisi yang mana pengambilan data ketika sedang duduk santai atau keadaan normal dan selanjutnya keadaan beraktivitas sedang yang diambil sampel olahraganya yaitu lari 100m.

Pengukuran keadaan normal atau sedang santai dan pengukuran keadaan sedang ketika berlari $100 \mathrm{~m}$ diberlakukan pengukuran menggunakan alat yang telah dibangun dan ditampilkan pada mobile application. Pertama-tama dalam penggunaan aplikasi ini harus melakukan login dengan memasukkan username dan password dan setelah itu tekan tombol login yang ada di layar seperti pada gambar 8 .

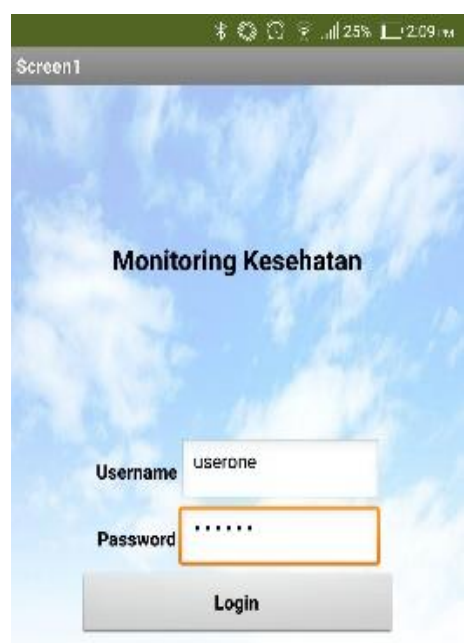

Gambar 8. User Login

Setelah memasukan data pada kolom username dan password pada halaman login, akan muncul main screen aplikasi dan setelah itu tekan tombol BT PORT untuk menghubungkan aplikasi dengan alat dan akan tampil bluetooth yang digunakan yaitu bluetooth HC-05. Setelah terhubung akan tampil nilai pada aplikasi dalam beberapa menit setelah pembacaan pada alat selesai seperti pada gambar 9 .

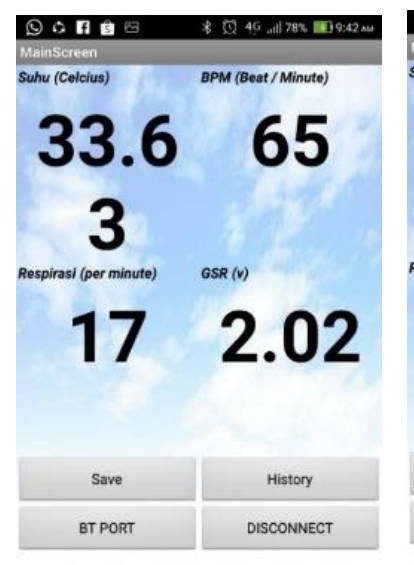

(a)

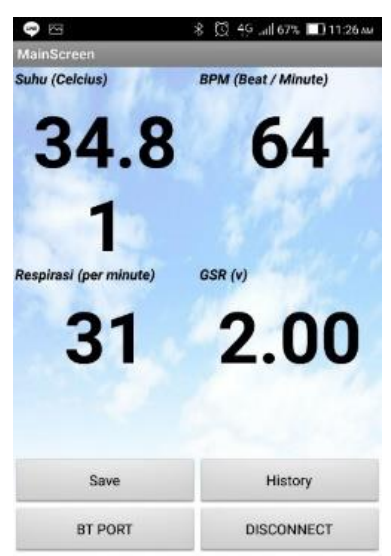

(b)
Gambar 9. a) Pembacaan data ketika sedang santai, b) Pembacaan ketika kondisi sedang lari $100 \mathrm{~m}$

Dari data yang didapatkan dapat disimpulkan nilai-nilai sensor yang dibaca dapat ditampilkan pada LCD dan data juga dapat dikirim pada mobile application melalui bluetooth yang sudah tertanam pada alat, dalam pengiriman data ke smartphone 
harus menunggu data masuk terlebih dahulu dalam satu menit setelah pembacaan data di alat.

Setelah pembacaan data di simpan menggunakan tombol save pada layar dan dapat dilihat riwayatnya pada history seperti diperlihatkan pada gambar 10 .

\begin{tabular}{l} 
07/19/2019 09:26:01 AM \\
suhu $=33.63$ Celcius \\
Detak Jantung $=65 \mathrm{BPM}$ \\
Pernapasan $=17 \mathrm{kali} / \mathrm{menit}$ \\
Keringat $=2.02 \mathrm{v}$ \\
\hline $07 / 19 / 201911: 25: 41 \mathrm{AM}$ \\
suhu $=34.81$ Celcius \\
Detak Jantung = 64 BPM \\
Pernapasan $=31 \mathrm{kali} / \mathrm{menit}$ \\
Keringat $=2.00 \mathrm{v}$
\end{tabular}

Gambar 10. Tampilan Riwayat pada History

Setelah pengujian didapatkan data seperti yang tertera pada gambar 11 .

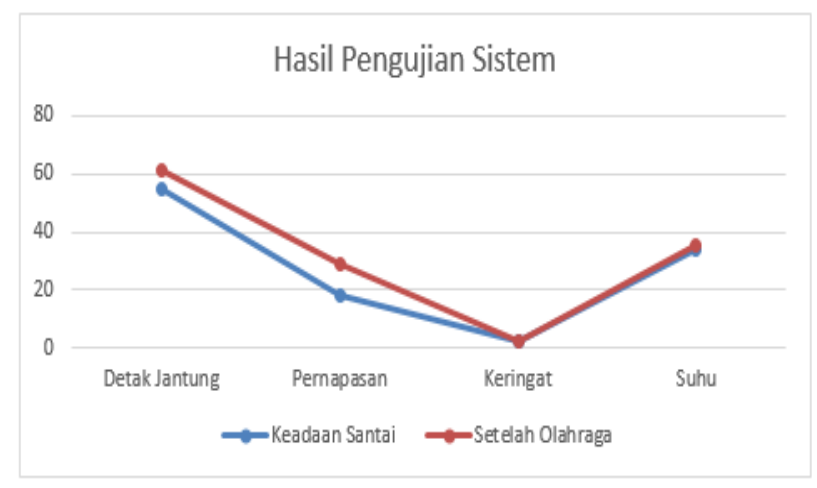

Gambar 11. Hasil pengujian sistem

Berdasarkan hasil pengujian ini untuk pulse sensor didapatkan rata-rata detak jantung dengan nilai 54 BPM, dalam keadaan sedang yaitu setelah lari 100m didapatkan nilai 61 BPM, jika dibandingan dengan nilai literatur BPM dalam kondisi normal antara kisaran 60-100. Nilai hasil yang didapatkan lumayan berbeda dengan literatur. Hal ini disebabkan beberapa hal yang pada saat peletakan sensor pada jari yang tidak tepat sehingga sensor tidak membaca dengan jelas. Namun nilai yang didapatkan dari kondisi normal ke kondisi setelah lari 100m terjadi peningkatan.

Hasil pembacaan pernapasan menggunakan sensor suara didapatkaan nilai rata-rata dari data yang didapatkan dalam keadaan santai dengan nilai $18 \mathrm{kali} /$ menit, sedangkan untuk kondisi sedang ketika setelah lari 100m didapatkan rata-rata nilai 29 kali/menit. data yang didapatkan sama antara kondisi santai dengan literatur yang kisaran pernapasan dalam 1 menit yaitu 12-20 kali per menitnya. Dan terjadi peningkatan pernapasan setelah berlari $100 \mathrm{~m}$.

Selanjutnya yaitu pembacaan suhu tubuh didapatkan rata-rata nilainya yaitu 34,19 ketika kondisi santai dan didapatkan nilai ketika kondisi sedang yaitu setelah berlari $100 \mathrm{~m}$ didapatkan ratarata 35,18 derajat celcius. Nilai yang didapat ketika kondisi santai meningkat ketika sudah berlari 100m. Namun nilai yang dibaca masih tergolong rendah dibandingkan nilai seharusnya dimana untuk suhu normal berada pada kisaran 36,5-37,2 derajat celcius.

\section{KESIMPULAN}

Dari hasil hasil pengujian dan analisa sistem sudah dapat menggabungkan sensor - sensor yang digunakan dalam satu mikrokontroler yakni arduino, pembacaan data secara continue berlanjut yang bermula pembacaan detak jantung, pernapasan, gsr dan suhu, selanjutnya menampilkan data pada smartphone android dengan mobile application dan terakhir sistem mampu menyimpan rekam data pembacaan di riwayat pada smartphone android. Percobaan yang telah dilakukan pembacaan oleh alat sudah cukup baik dan data yang ditampilkan pada aplikasi mobile pada smartphone sesuai dengan alat dan penyimpanan data pembacaan sudah baik. Nilai yang didapatkan ketika keadaan santai terjadi peningkatan setelah beraktivitas seperti olahraga lari $100 \mathrm{~m}$, diantaranya peningkatan detak jantung yakni 54 BPM ke 61 BPM setelah lari 100m. peningkatan pernapasan yaitu $18 \mathrm{kali} /$ menit ke $29 \mathrm{kali} /$ menit serta didapatkan juga peningkatan suhu dari 34.19 C ke 35,18 C.

\section{DAFTAR PUSTAKA}

[1] I. M. Naradhyana, U. Sunarya, and S. Hadiyoso, "Alat Pemantau Sist. Pernafasan Menggunakan Mikrokontroller dan E-Health PCB," $e$ Proceeding of Applied Science, Vol. 1, No. 1, 2015.

[2] A. Iqlimah and M. Julius, "Perancangan alat ukur volume udara pernapasan manusia," J. Mhs. TEUB, Vol. 1, No. 1, 2013.

[3] A. Zainudin, E. Rahmawati, and Dzulkiflih, "Pengukuran Volume Paru-Paru Dengan Memanfaatkan Sensor Tekanan," J. Inov. Fis. 
Indones. Vol., vol. 04, pp. 127-132, 2015.

[4] Rustiana, "Rancang Bangun Alat Kalibrator Gas Flowmeter," in Prosiding Seminar Nasional Kesehatan Politeknik Kesehatan Kementerian Kesehatan Surabaya, 2019, pp. 178-181.

[5] A. Prasetyo, P. N. Hafizah, I. D. Rahmawati, M. F. Arief, I. Indriani, and A. Parastiwi, "Monitoring Suhu Tubuh Pasien Demam Berdarah Menggunakan Bluetooth yang Diintegrasikan Ke Personal Komputer," Pros. SENTIA 2015 - Politek. Negeri Malang, vol. 7, 2015.

[6] L. Vorvick, "Body temperature norms," MedlinePlus, pp. 4-7, 2017.

[7] E. Nurazizah, M. Ramdhani, and A. Rizal, "Rancang Bangun Termometer Digital Berbasis Sensor DS18B20 Untuk Penyandang Tunanetra," Proceeding Eng., Vol. 4, No. 3, pp. 3294-3301, 2017.

[8] M. P. Lukman and H. Surasa, "Portable Monitoring Penderita Penyakit Jantung Terhadap Serangan Berulang Berbasis Android," Pros. Seminar Nasional Teknologi Informasi, pp. 20-26, 2017.

[9] M. Nurdin, N. Aminah, Syahrir, F. Djamil, and M. F. Hamdani, "Deteksi Denyut Jantung Dengan Metode Sensor Pulsh Berbasis Arduino," Pros. Semin. Nas. Tek. Elektro Inform. SNTEI, pp. 201-206, 2015.
[10] D. Putri, P. Indriani, and E. L. Utari, "Perancangan Pulse Oximetry Dengan Sistem Alarm Prioritas Sebagai Vital Monitoring," Vol . IX Nomor 27 Nop. 2014 - J. Teknol. Inf., pp. 93-107, 2014.

[11] Y. Ferdinan, "Efisiensi Daya untuk Pantauan Data Heart Rate Menggunakan Metode Idle Time-Deep Sleep," [Tugas Akhir], Stikom Surabaya, 2019.

[12] A. D. Septiani, "Perancangan Alat Pemantau Kondisi Kesehatan Manusia," Edu Elektrika Journal, Vol. 4, No. 2, pp. 44-47, 2015.

[13] M. Cardona-Morrell et al., "Vital signs monitoring and nurse-patient interaction: A qualitative observational study of hospital practice," Int. J. Nurs. Stud., Vol. April, pp. 9-16, 2015.

[14] W. A. B. M. Haryanto, "Rancang Bangun Alat Ukur Detak Jantung dan Suhu Tubuh Manusia Berbasis Mikrokontroler Atmega 16," J. Ilm. Go Infotech, Vol. 20, No. 1, 2014.

[15] R. Adil, and W. A. N. Projo, "Pembuatan alat bantu pemantau kondisi tubuh dan keberadaan seseorang saat beraktifitas dengan tampilan web," [Tugas Akhir], Politeknik Elektronika Negeri Surabaya, 2005. 